\title{
Comparison of Blood Metabolites and Enzyme Activities at Different Slaughter Ages of Hanwoo Cattle
}

\author{
Do Hyung $\mathrm{Kim}^{2}$, Kyoung Hoon $\mathrm{Kim}^{1}$, In Sik Nam${ }^{3}$, Wan Young $\mathrm{Kim}^{4}$, Joon $\mathrm{Mo} \mathrm{Yeo}^{4}$, Sung Sill Lee, Jong Cheol $\mathrm{Ju}^{6}$ \\ and Young Kyoon $\mathrm{Oh}^{1 *}$ \\ ${ }^{1}$ National Institute of Animal Science, RDA, Korea, ${ }^{2}$ Department of Animal and Food Sciences, University of Kentucky, \\ USA, ${ }^{3}$ Korea Livestock Products HACCP Accreditation Service, Korea, ${ }^{4}$ Korea National College of Agriculture and Fisheries, \\ Korea, ${ }^{5}$ Division of Applied Life Science (BK21 program), Gyeongsang National University, Korea, ${ }^{6}$ Department of Animal \\ Husbandry, Cheonan Yonam College, Korea
}

\begin{abstract}
This study was conducted to investigate changes of blood metabolites and enzyme activities at different slaughter ages of Hanwoo cattle. Blood samples were taken from six hundred thirty two steers (24 33 months of age) and one hundred twenty eight bulls (17 24 months of age) by venipuncture from caudal vein immediately prior to slaughter. Glucose concentrations were linearly increased $(\mathrm{P}<0.001)$ with increases of the slaughter age in steers, and blood urea nitrogen $(\mathrm{BUN})$ concentrations were linearly decreased $(\mathrm{P}<0.001)$ with increases of the slaughter age in steers. Likewise, glucose and albumin concentrations in bulls were linearly decreased $(\mathrm{P}=0.009$ and $\mathrm{P}<0.001$, respectively) with increases of the slaughter age. BUN, cholesterol, triglycerides, and total cholesterol concentrations were linearly increased $(\mathrm{P}<0.001,0.018$ and 0.002 , respectively), and creatinine concentrations were quadratically increased $(\mathrm{P}=0.009)$ with increases of the slaughter age. Activity of gamma glutamyltransferase $(\gamma-\mathrm{GT})$ and aspartate aminotransferase (AST) was linearly increased $(\mathrm{P}<0.001)$ with increases of the slaughter age in both steers and bulls, whereas alanine aminotransferase (ALT) was not affected by increasing slaughter age. In addition, the concentrations of $\gamma-\mathrm{GT}$ and AST were higher $(\mathrm{P}<0.05)$ for bulls than those of steers at 24 months of age. Increased levels of $\gamma$-GT and AST indicate impaired liver function; it may be associated with increases of concentrate level which is a concomitant of the extended fattening periods in Hanwoo feeding. In conclusion, the results in the present study may be one of the useful information for diagnosis of the metabolic disorder in Hanwoo cattle
\end{abstract}

(Key words : Blood metabolites, Blood enzyme activity, Slaughter ages, Hanwoo cattle)

\section{INTRODUCTION}

Recently, Hanwoo industry has been increasingly adopting extended fattening period (more than 30 months of age) in order to produce a high grade of Hanwoo beef, thereby, the fattening period isusually coupled with increased concentrate level (up to 95\%) in the diet. Even feeding concentrate only throughout the finishing phase has become a routine practice in Hanwoo bulls (RDA, 2007). Although feeding a highconcentrate diet can be favorable for increasing beef quality, it can drop ruminal $\mathrm{pH}$ below 6.0 which causes the ruminal disturbance and increase the risk of acidosis. Consequently, lengthy fattening periodmay have an adverse effect on animal's health because it could induce acidosis, bloat, and liver abscess
Changes of blood metabolites in ruminants have been used as a criterion of nutrient status (Russel, 1984) and as an index of metabolic disturbance (Rankins et al., 1991; Puoli et al., 1992). The concentration of specific enzymes in serum serves as indicators of tissue damage or metabolic disorders (Kramer, 1989). Hepatic dysfunction that can be induced by a high-concentrate diet in the ruminants has been documented by elevated serum protein, bilirubin, and enzyme activities such as alanine aminotransferase, aspartate aminotransferase, and gamma-glutamyltransferase (Lechtenberg and Nagaraja. 1991). Accordingly, blood profiling is considered to be one of the significant sources for judging the nutrient status and body condition, and a comparison of some blood metabolites and enzyme activities in ruminants may be used for diagnosis of the metabolic disorder. However, the effects

* Corresponding author: Young Kyoon Oh, Animal Nutrition \& Physiology Team, National Institute of Animal Science, RDA, Suwon, 441-706 Korea. Tel: 031-290-1665, Fax: 031-290-1660, E-mail: oh665@korea.kr 
of the extended fattening period with a high-concentrate diet on hematologic aspectin Hanwoo cattle is not well established and properly understood. Therefore, this study was conducted to collect the blood data and investigate the changes in blood metabolites and enzyme activities at different slaughter ages of Hanwoo cattle fed a high-concentrate diet.

\section{MATERIALS AND METHODS}

\section{Experimental procedures}

This experiment was conducted at National Livestock Cooperative Federation in Bucheon, South Korea. Of the shipped cattle to the abattoir, six hundred thirty two steers (24 33 months of age) and one hundred twenty eight bulls (17 24 months of age), which were raised with a highconcentrate diet (over $90 \%$ of total feed) at the late fattening phase, were randomly selected for blood collection. Blood samples were taken by venipuncture from caudal vein immediately prior to slaughter between 0500 and 0600 in the morning, a day after the cattle shipment to the abattoir. Thus, the cattle were fasted for $24 \mathrm{~h}$ prior to blood collection. Blood samples were collected into $10 \mathrm{~mL}$ vacuum tubes (BD Vacutainer, Becton \& Dickinson, NJ, USA) without any anticoagulant, and allow the blood to clot for $\mathrm{l} \mathrm{h}$ at ambient temperature. Serum samples were separated after centrifugation $\left(2,000 \times \mathrm{g}\right.$ at $4^{\circ} \mathrm{C}$ for $\left.20 \mathrm{~min}\right)$ and stored $(-20$ $\left.{ }^{\circ} \mathrm{C}\right)$ until analysis

\section{Blood metabolites and enzyme activities}

Blood samples were analyzed by an automatic blood analyzer (Express Plus, Ciba-Corning, CA, USA) for metabolites and enzyme activities. Total protein (TP), glucose, blood urea nitrogen (BUN), albumin, and creatinine concentrations were analyzed according to the biuret method of Flack and Woollen (1984), the hexokinase method of Farrance (1987), the urease method of Rocch-Ramel (1967), the bromocresol green method of Doumas et al. (1971), and the picric acid method of Husdan and Rapoport (1968), respectively

Total cholesterol (TC), triglycerides (TG), calcium, inorganic phosphorus (IP), and iron concentrations were analyzed using the method of Allain et al. (1974), the method of McGowan et al. (1983), the cresolphthalein complexone method of Moorehead and Briggs (1974), the method of Daly and
Estingshausen(1972), and the method of Higgins (1981), respectively

Serum aspartate aminotransferase (AST) and alanine aminotransferase (ALT) activities were analyzed by the International Federation of Clinical Chemistry and Laboratory Medicine method (1986a,b), and serum gamma glutamyltransferase $(\gamma$ GT) activities were measured by the method of Rosalki and Tarlow (1974).

\section{Statistical analysis}

Data obtained from the blood analysis was subjected to statistical analysis using the GLM procedure (SAS Inst. Inc., Cary, NC) according to the model: $Y_{i j}=\mu+A_{i}+S_{j}+(A \times S)_{i j}$ $+e_{i j}$, where $Y_{i j}, \mu, A_{i}, S_{j},\left(A \times S_{i j}\right.$ and $e_{i j}$ are the response, overall mean, mean effect of animal $i$, mean effect of slaughter age $\mathrm{j}$, and interaction between animal and slaughter age and random residual error, respectively

An orthogonal contrast was used to assess linear and quadratic relationships between the slaughter age and the dependent variable. Orthogonal coefficients for unequally spaced slaughter ages were acquired using procedure Interactive Matrix Language (SAS Inst. Inc.). Duncan's multiple range test was used to determine significant differences between bulls and steers at thesame slaughter age (24 months of age). Effects were declared significant at $\mathrm{P}<0.05$.

\section{RESULTS}

Changes of serum metabolites, enzyme activities, and body weight at different slaughter ages in Hanwoo steers are presented in Table 1. Glucose concentrations in steers were linearly $(\mathrm{P}<0.001)$ and quadratically $(\mathrm{P}=0.008)$ increased with increases of the slaughter age, whereas BUN concentrations were linearly decreased $(\mathrm{P}<0.001)$ with increases of the slaughter age. The $\gamma$-GT $(\mathrm{P}=0.007)$ and AST $(\mathrm{P}=0.001)$ activities were linearly increased with increasing slaughter age. However, serum ALT activities were not affected by slaughter age

Changes in serum metabolites, enzyme activities, and body weight at different slaughter ages in bulls are presented in Table 2. Glucose and albumin concentrations in bulls were linearly ( $\mathrm{P}=0.009, \quad<0.001$, respectively) decreased with increasing slaughter age, whereas BUN, TG, and cholesterol concentrations were linearly increased with increasing slaughter age $(\mathrm{P}<0.001,0.018$, and 0.002 , respectively). The 
Kim et al. ; Blood Metabolites and Enzyme Activities of Hanwoo

Table 1. Changes in serum metabolites, enzyme activities, and body weight by different slaughter ages in Hanwoo steers

\begin{tabular}{|c|c|c|c|c|c|c|c|c|c|c|c|c|}
\hline \multirow{2}{*}{ Items $^{1)}$} & \multicolumn{9}{|c|}{ Slaughter age, months } & \multirow{2}{*}{ SEM } & \multicolumn{2}{|c|}{$\begin{array}{c}\text { Statistical } \\
\text { significance }^{2)}\end{array}$} \\
\hline & 24 & 25 & 26 & 27 & 28 & 29 & 30 & 31 & 33 & & Linear & Quadratic \\
\hline No. of steers & 42 & 25 & 66 & 27 & 113 & 57 & 257 & 29 & 16 & & & \\
\hline Glucose, mg/dl & 84.45 & 63.35 & 96.71 & 94.05 & 91.20 & 94.36 & 90.48 & 104.91 & 92.89 & 3.05 & $<001$ & 0.008 \\
\hline BUN, mg/dl & 19.34 & 18.22 & 16.91 & 14.01 & 16.62 & 16.06 & 15.74 & 14.08 & 14.08 & 0.57 & $<.001$ & 0.067 \\
\hline $\mathrm{TG}, \mathrm{mg} / \mathrm{dl}$ & 19.08 & 18.44 & 18.64 & 18.84 & 16.98 & 16.75 & 16.99 & 18.69 & 18.88 & 0.97 & 0.654 & 0.123 \\
\hline $\mathrm{TC}, \mathrm{mg} / \mathrm{dl}$ & 178.39 & 172.00 & 181.56 & 161.16 & 177.47 & 184.95 & 185.08 & 174.91 & 176.95 & 6.14 & 0.605 & 0.893 \\
\hline $\mathrm{TP}, \mathrm{mg} / \mathrm{dl}$ & 6.24 & 6.10 & 6.52 & 6.15 & 6.20 & 6.28 & 6.34 & 6.17 & 6.35 & 0.06 & 0.436 & 0.752 \\
\hline Creatinine, $\mathrm{mg} / \mathrm{dl}$ & 1.33 & 1.28 & 1.27 & 1.33 & 1.32 & 1.30 & 1.30 & 1.36 & 0.35 & 0.03 & 0.259 & 0.386 \\
\hline Albumin, g/dl & 4.68 & 4.56 & 4.65 & 4.44 & 4.57 & 4.57 & 4.61 & 4.46 & 4.54 & 0.04 & 0.069 & 0.265 \\
\hline $\mathrm{Ca}, \mathrm{mg} / \mathrm{dl}$ & 7.95 & 7.25 & 7.53 & 8.20 & 7.75 & 7.74 & 7.45 & 7.91 & 7.98 & 0.16 & 0.318 & 0.498 \\
\hline $\mathrm{IP}, \mathrm{mg} / \mathrm{dl}$ & 5.27 & 5.43 & 5.01 & 4.78 & 5.23 & 4.84 & 5.05 & 5.02 & 4.88 & 0.16 & 0.088 & 0.403 \\
\hline Iron, $\mathrm{mg} / \mathrm{dl}$ & 1.07 & 1.55 & 1.06 & 1.26 & 1.24 & 1.08 & 1.27 & 1.62 & 0.91 & 0.12 & 0.559 & 0.050 \\
\hline$\gamma-\mathrm{GT}, \mathrm{u} / \mathrm{l}$ & 24.79 & 28.64 & 26.27 & 27.00 & 29.86 & 28.32 & 28.27 & 28.52 & 35.25 & 1.87 & 0.007 & 0.288 \\
\hline AST, u/l & 88.72 & 94.86 & 93.80 & 104.25 & 96.38 & 112.01 & 98.96 & 97.95 & 113.03 & 4.01 & 0.001 & 0.727 \\
\hline $\mathrm{ALT}, \mathrm{u} / \mathrm{l}$ & 18.93 & 19.83 & 22.56 & 18.86 & 19.66 & 22.34 & 20.81 & 17.63 & 19.74 & 0.76 & 0.651 & 0.132 \\
\hline $\mathrm{BW}, \mathrm{kg}$ & 603.02 & 609.20 & 639.46 & 635.22 & 648.06 & 651.51 & 665.84 & 696.76 & 703.59 & 8.72 & $<.001$ & 0.124 \\
\hline
\end{tabular}

Table 2. Changes in serum metabolites, enzyme activities, and body weight by different slaughter ages in Hanwoo bulls

\begin{tabular}{|c|c|c|c|c|c|c|c|c|}
\hline \multirow{2}{*}{ Items $^{1)}$} & \multicolumn{5}{|c|}{ Slaughter age, months } & \multirow{2}{*}{ SEM } & \multicolumn{2}{|c|}{ Statistical significance ${ }^{2)}$} \\
\hline & 17 & 20 & 21 & 22 & 24 & & Linear & Quadratic \\
\hline No. of bulls & 13 & 41 & 38 & 22 & 14 & & & \\
\hline Glucose, mg/dl & 93.00 & 90.61 & 95.45 & 77.67 & 81.21 & 3.14 & 0.009 & 0.341 \\
\hline $\mathrm{BUN}, \mathrm{mg} / \mathrm{dl}$ & 13.15 & 13.42 & 15.91 & 20.57 & 18.56 & 0.82 & $<.001$ & 0.860 \\
\hline $\mathrm{TG}, \mathrm{mg} / \mathrm{dl}$ & 9.50 & 10.98 & 10.50 & 15.17 & 13.43 & 1.20 & 0.018 & 0.950 \\
\hline $\mathrm{TC}, \mathrm{mg} / \mathrm{dl}$ & 134.38 & 153.82 & 164.95 & 181.46 & 181.50 & 9.48 & 0.002 & 0.674 \\
\hline $\mathrm{TP}, \mathrm{mg} / \mathrm{dl}$ & 6.14 & 6.16 & 6.18 & 6.31 & 6.13 & 0.07 & 0.699 & 0.322 \\
\hline Creatinine, $\mathrm{mg} / \mathrm{dl}$ & 1.38 & 1.30 & 1.28 & 1.41 & 1.47 & 0.04 & 0.148 & 0.009 \\
\hline Albumin, g/dl & 4.69 & 4.65 & 4.42 & 4.37 & 4.35 & 0.06 & $<.001$ & 0.177 \\
\hline $\mathrm{Ca}, \mathrm{mg} / \mathrm{dl}$ & 7.26 & 7.14 & 7.11 & 7.13 & 7.49 & 0.20 & 0.627 & 0.197 \\
\hline $\mathrm{IP}, \mathrm{mg} / \mathrm{dl}$ & 5.95 & 6.03 & 5.92 & 5.72 & 5.48 & 0.17 & 0.104 & 0.196 \\
\hline Iron, $\mathrm{mg} / \mathrm{dl}$ & 1.70 & 1.84 & 1.52 & 1.50 & 1.79 & 0.11 & 0.879 & 0.361 \\
\hline$\gamma-\mathrm{GT}, \mathrm{u} / \mathrm{l}$ & 30.31 & 31.12 & 33.50 & 36.73 & 49.79 & 3.49 & 0.002 & 0.031 \\
\hline AST, u/l & 95.02 & 98.22 & 107.09 & 119.23 & 132.51 & 7.05 & 0.001 & 0.195 \\
\hline ALT, u/l & 18.84 & 18.86 & 19.94 & 21.12 & 19.34 & 0.92 & 0.445 & 0.475 \\
\hline BW, kg & 576.92 & 585.46 & 606.92 & 644.82 & 647.43 & 10.67 & $<001$ & 0.423 \\
\hline
\end{tabular}

${ }^{1)} \mathrm{BUN}$ : blood urea nitrogen; TG: triglyceride; TC: total cholesterol; TP: total protein; IP: inorganic phosphorus; $\gamma-\mathrm{GT}$ : gamma glutamyltransferase; AST: aspartate aminotransferase; ALT: alanine aminotransferase.

2) Statistical significance of linear and quadratic effects were tested by contrast statement of GLM procedure. 


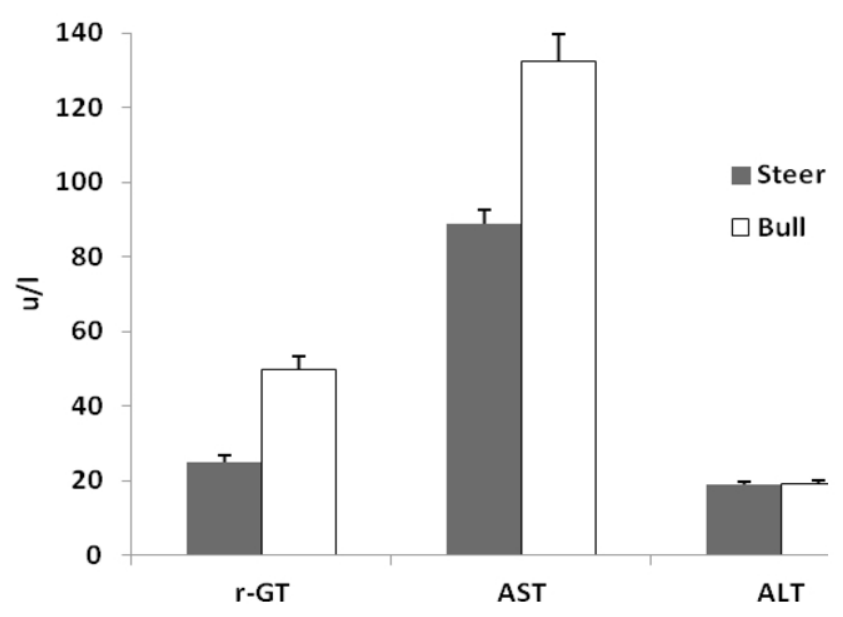

Fig. 1. Comparison of serum enzyme activities between Hanwoo steers and bulls at 24 months of age. Error bars are SE.

$\gamma$-GT and AST activities were linearly increased $(\mathrm{P}=0.002$ and $\mathrm{P}=0.001$, respectively) with increasing slaughter age in bulls. However, ALT activities were not affected by aging. Activities of $\gamma$-GT and AST were higher $(\mathrm{P}<0.05)$ for bulls than those of steers at 24 months of age (Fig. 1). However, ALT levels were not significantly different between steers and bulls.

\section{DISCUSSION}

Fattening period of Hanwoo cattle hasbeen extending in order to increase beef quality grades, especially marbling score. Feeding a high-concentrate or concentrate diet alone throughout the finishing phase has become a routine practice. It has been well-established that high concentrate diets supported higher total VFA concentrations and higher proportions of propionate relative to acetate in cattle (Hungate, 1966). Propionate is a major glucose precursor in ruminants. Over $80 \%$ of propionate absorbed into the portal blood is utilized for glucose synthesis (Steinhour and Bauman, 1988). The results of the present study also indicate that most of the glucose turnover in ruminants is derived from propionate and are in agreement with present findings. Urea is produced in the liver and excreted via the kidneys into urine. Consequently, the circulating levels of urea depend upon protein intake, catabolism, and kidney function. Elevated urea levels can occur with dietary changes, diseases which impair kidney function, liver disease, diabetes, and infection (Burtis and Ashwood, 1994). In Korea, the feeding strategy for producing a quality beef, the $\mathrm{CP}$ content of concentrate in the diet is reduced according to increase in fattening duration( $\mathrm{Kim}$ et al., 2005). On the other hand, BUN concentrations in bulls were linearly increased with increasing of the slaughter age, this may be a result of lower nitrogen utilization in digestive tract. Serum cholesterol concentrations were linearly increased $(\mathrm{P}=0.002)$ with increasing slaughter age in bulls only. Adipose tissue is the cholesterol storage site, whereas tissue cholesterol concentrations were not related to serum cholesterol (Wheeler et al., 1987). The relation of increase cholesterol concentrations in the blood and increased body fat is unclear. The blood cholesterol and triglyceride concentrations varied in ruminants fed fat-rich diets (Skeaff et al., 2004). Meanwhile, the cholesterol levels are important in the diagnosis and classification of hyperlipoproteinaemias. Stress, age, gender, hormonal balance, and pregnancy affect normal cholesterol level(Burtis and Ashwood, 1994). The increase of protein synthesis in the muscle decreases the blood albumin concentrations. Albumin is used for the accumulation of protein to the muscle (Galbraith et al., 1978). Therefore, the decrease of albumin concentrations may be a result associated with aging, which can infer from body weight that was linearly increased with aging in both steers and bulls. In addition, it may be because of increasing concentrate feeding associated with increases of the fattening periods.

The blood metabolites in the present study are in accordance with the findings of Lee et al. (1997) and Ahn et al. (2000) when compared with 25 months of age and 600 $\mathrm{kg}$ Hanwoo steers, with TP, TC, albumin, and glucose concentration were reported at $7.8 \mathrm{~g} / \mathrm{dl}, 140.1 \mathrm{mg} / \mathrm{dl}, 3.7 \mathrm{~g} / \mathrm{dl}$, and $57.6 \mathrm{mg} / \mathrm{dl}$, respectively, at 25 months of age, and TG, TC, TP, and glucosein $600 \mathrm{~kg}$ Hanwoo steers have range of $17.8 \sim 22.0 \mathrm{mg} / \mathrm{dl}, \quad 144.3 \sim 159.0 \mathrm{mg} / \mathrm{dl}, \quad 6.6 \sim 6.9 \mathrm{~g} / \mathrm{dl}$, and $63.5 \sim$ $70.5 \mathrm{mg} / \mathrm{dl}$, respectively.

Increase in serum $\gamma$-GT levels was confirmed in all forms of liver disease or damage (Kachmar and Moss, 1976). Clinical reports established that serum $\gamma$-GT in calves was increased by liver infection where it was 3 to 20 times higher than normal (Anderson et al., 1977). Serum AST is a good indicator of hepatic damage as well, and it is commonly measured clinically as a marker for liver health. Zadnik (2003) reported that the AST activity of healthy cows was $60.2 \pm 12.1 \mathrm{IU} / \mathrm{L}$. Ahn et al. (2000) reported that the AST activity with the levels of concentrate $\operatorname{diet}(84,87$, and $89 \%$ of total feed) in Hanwoo steers was $82.75 \pm 5.75,90.25 \pm$ 15.45 , and $80.40 \pm 9.46 \mathrm{u} / \mathrm{L}$, respectively. Damage or disease 
to some body tissues such as myocardial infarction, viral hepatitis, liver necrosis, cirrhosis, and muscular dystrophy may result in increased serum or plasma levels of AST (Zilva and Pannall, 1979). In addition, Lechtenberg and Nagaraja (1991) detected that rectal temperature, leukocyte counts, fibrinogen, globulin, bilirubin, $\gamma$-GT, and sorbitol dehydrogenase concentrations increased when hepatic abscesses were induced experimentally in steers by inoculating Fusobacterium necrophorum via ultrasonography-guided, percutaneous catheterization of the portal vein. Therefore, the increased levels of $\gamma$-GT and AST with increases of the slaughter ages may be associated with a high-concentrate diet because extension of fattening period is usually coupled with increase of a high-concentrate diet in Hanwoo industry. In addition, a strategy to quickly increase meat yield by feeding over 95\% high-concentrate diet at the late fattening phase before slaughter has become a routine practice in Hanwoo industry. Cattle fed a high-concentrate diet are energetically more efficient for increasing beef quality and yield compared with feeding a high-fiber diet, however, it has been reported that feeding a high-concentrate diet decreased and(or) fluctuated feed intake in finishing phase (Shin et al., 2002). The erratic feed intake in the finishing phase may result from decreased ruminal $\mathrm{pH}$ below 6.0 or erratic $\mathrm{pH}$ because the decreased and erratic ruminal $\mathrm{pH}$ can cause the rumen disturbance and an acidic condition which can increase the risk of ruminal acidosis (Nocek, 1997). Moreover, an acidic condition can damage the ruminal wall which predispose to ruminal abscess by Fusobacterium necrophorum. In addition, the bacteria can gain entry to the portal circulation and subsequently causes bacterial emboli in the portal circulation or filters by liver. Therefore, as a result of feeding a highconcentrate diet liver infections and abscess can occur in the cattle.

The $\gamma$-GT and AST levels in the present study were higher $(\mathrm{P}<0.05)$ for bulls than those of steers at the same age of 24 months. Such difference of serum enzymes level between bulls and steers at the same age may result from differences in the fattening periods, feeding management, and feed intake. The fattening periods of the bull is generally shorter than those of the steer and to increase energy supply for bulls, feeding a concentrate diet only throughout the finishing phase has become a routine practice (RDA, 2007), as mentioned above. Although feed intake was not monitored, it was assumed that normally bulls consume more feed than steers as the body weight of bulls was higher than that of steers in the present study. The general feeding management of Hanwoo cattle during the finishing phase is feeding concentrate prior to roughage or even all concentrate diet in order to increase concentrate intake. The roughage is restricted below $10 \%$ of the total feed intake at the late fattening phase (RDA, 2007). Such concentrate-centered feeding managements would develop an acidic rumen condition. Acid-induced rumenitis and damage of the ruminal wall are associated with a sudden change to high energy diets and other dietary indiscretions such as a change in feeding patterns, allowing cattle to become overly hungry, feeding unpalatable diets, and feeding very low roughage ratio (Elam, 1976).

Although all slaughtered cattle for this study were not raised in the same farm with a same diet, we used cattle for blood collection which were raised with a high-concentrate diet (over $90 \%$ of total feed) at the late fattening phase. Therefore, results in the present study may be one of the useful information in hematologic aspect that is linked with a high-concentrate diet and fattening period, and indicate that serum $\gamma$-GT and AST may be an important predictor for evaluating hepatic dysfunction in Hanwoo cattle. However, further study that is systematically designed by controlled diet and environment may be needed to provide more accurate indices about correlations among the hepatic dysfunction, the length of fattening period, and feeding a high-concentrate diet in Hanwoo cattle.

\section{REFERENCES}

Ahn, B. H., Lyu, J. S., Kang, H. B., Ahn, D. W. and Chung, J. S. 2000. Effects of levels of roughage on performance and beef quality of Hanwoo steers. J. Anim. Sci. \& Technol. (Kor.) 42(5):619-628.

Allain, C. C., Poon, L. S., Chan, C. S. G., Richmond, W. and Fu, P. C. 1974. Enzymatic determination of total serum cholesterol. Clin. Chem. 20:470-475.

Anderson, P. H., Berrett, S., Brush, P. J., Hebert, C. N., Parfitt, J. W. and Patterson, D. S. P. 1977. Biochemical indicators of liver injury in calves with experimental fasciolosis. Vet. Record 100:43-45.

Burtis, C. A. and Ashwood, E. R. 1994. Tietz Textbook of Clinical Chemistry. Second Edition, WB Saunders Company.

Daly, J. A. and Ertingshausen, G. 1972. Direct Method for Determining Inorganic Phosphate in Serum with the "CentrifiChem". Clin. Chem. 18:263-265. 
Doumas, B. T., Watson, W. and Biggs, H. G. 1971. Albumin standards and the measurement of serum albumin with bromocresol green. Clin. Chim. Acta. 31:87-96.

Elam, C. J. 1976. Acidosis in feedlot cattle: Practical observations. J. Anim. Sci. 43:898-901.

Farrance, I. 1987. Clin. Biochem. Reviews. 8:55-68.

Flack, C. P. and Wollen, J. W. 1984. Prevention of interference by dextran with biuret-type assay of serum protein. Clin. Chem. 30: 559-561.

Galbraith, H., Dempster, D. G. and Miller, T. B. 1978. A note on the effect of castration on the growth performance and concentrations of some blood metabolites and hormones in British Fresian male cattle. Anim. Prod. 26:339-342.

Hungate, R. E. 1966. The rumen and its microbes. Academic Press, New York.

Husdan, H. and Rapoport, A. 1968. Estimation of creatinine by the Jaffe reaction: A comparison of three methods. Clin. Chem. 14:222-238

IFCC Expert panel on enzymes part 3. 1986a. J. Clin. Chem. Clin Biochem. 24:481-495.

IFCC Method for L-aspatate aminotransferase. 1986b. J. Clin. Chem. Clin Biochem. 24:497-510.

Kachmar, J. F. and Moss, D. V. 1976. "Enzymes" in fundamentals of clinical chemistry. Tietz NW(Ed) WB Saunders Co. Philadelphia. page 621-623.

Kim, K. H., Lee, J. H., Oh, Y. G., Kang, S. W., Lee, S. C., Park, W. Y. and Ko, Y. D. 2005. The optimal TDN levels of concentrates and slaughter age in Hanwoo steers. J. Anim. Sci. \& Technol. (Kor.) 47(5):731-744

Kramer, J. W. 1989. Clinical enzymology. In: J. J. Kaneko (Ed.) Clinical Biochemistry of Domestic Animals (4th Ed.). pp 338-363. Academic Press, San Diego, CA.

Lechtenberg, K. F. and Nagaraja, T. G. 1991. Hepatic ultrasonography and blood changes in steers with experimentally induced liver abscesses. Am. J. Vet. Res. 52:803-809.

Lee, S. S., Cheong, J. K., Park, N. H. and Won, Y. S. 1997. Effects of castration on the carcass characteristics and serum metabolites in Korean cattle. J. Anim. Sci. \& Technol. (Kor.) 39(2):145-154.

McGowan, M. W., Artiss, J. D., Strandbergh, D. R. and Zak, B. 1983. A peroxidase-coupled method for the colorimetric determination of serum triglycerides. Clin. Chem. 29:538-542.

Moorehead, W. R. and Briggs, H. C. 1974. Clin. Chem. 20:1458. (As cited in ERBA Manheim Kit for Ca estimation).
Nagaraja. T. G. and Chengappa, M. M. 1998. Liver abscesses in feedlot cattle (A review). J. Anim. Sci. 76:287-298.

Nocek, J. E. 1997. Bovine acidosis: Implications on laminitis. J. Dairy. Sci. 80:1005-1028.

Puoli, J. R., Reid, R. L. and Belesky, D. P. 1992. Photosensitization in lambs grazing switchgrass. Agron. J. 84:1077-1080.

Rankins, D. L., Jr., Smith, G. S. and Hallford, D. M. 1991. Serum constituents and metabolic hormones in sheep and cattle fed Kochia scoparia hay. J. Anim. Sci. 69:2941-2946.

Rocch-Ramel, F. 1967. An enzymic and fluorophotometric method for estimating urea concentrations in nanoliter specimens. Anal. Biochem. 21:372-381

Rosalki, S. B. and Tarlow, D. 1974. Optimized determination of $\gamma$-glutamyl- transferase by reaction rate analysis. Clin. Chem. 20:1121-1124.

RDA. 2007. The standard farming textbook. Hanwoo. 6th edition.

Russel, A. J. F. 1984. Means of assessing the adequacy of nutrition of pregnant ewes. Livest. Prod. Sci. 11:429-436.

Shin, K. J., Oh, Y. G., Lee, S. S., Kim, K. H., Kim, C. H. and Park, B. H. 2002. Feed intake evaluation of korean cattle (Hanwoo) fed diets containing different levels of compound feed in the growing and fattening periods. J. Anim. Sci. \& Technol. (Kor.) 44(1):95-104.

Skeaff, C. M., Williscroft, K., Mann, J. and Chisholm, A. 2004. Replacing cows' with sheep's dairy fat lowers plasma cholesterol concentration in participants consuming dairy fat-rich diets. Eur. J. Clin. Nutr. 58:250-257.

Steinhour, W. D. and Bauman, D. E. 1988. Propionate metabolism: A new interpretation. p. 238-256 in Aspects of digestive physiology in ruminants. A. Dobson and M. J. Dobson, ed. Comstock Publ. Assoc., Ithaca, NY.

Wheeler, T. L., Davis, G. W., Stoecker, B. J. and Harmon, C. J. 1987. Cholesterol concentration on longissimus muscle, subcutaneous fat and serum of two beef cattle breed types. J. Anim. Sci. 65:1531-1537.

Zadnik, T. 2003. A comparative study of the hemato-biochemical parameters between clinically healthy cows and cows with displacement of the abomasum. Acta Vet. Beograd. 53:297309.

Zilva, J. F. and Pannall, P. R. 1979. "Plasma enzymes in diagnosis" in clinical chemistry in diagnosis and treatment. LLoyd-Luke London. Chap. 15:338-339.

(Received Sep. 21, 2012; Revised Nov. 30, 2012; Accepted Dec. 8, 2012) 